\title{
Könyvszemle
}

SIPOS JÚLIA GONDOZÁSÁBAN

\section{VÉKÁS LAJOS: FEJEZETEK A MAGYAR MAGÁNJOGTUDOMÁNY TÖRTÉNETÉBŐL}

Vékás Lajos, a Magyar Tudományos Akadémia rendes tagja, egyetemi tanár könyve 2019 végén jelent meg. A kötet nyolc, saját tudományterülete, elsősorban a magánjog (polgári jog) meghatározó, kimagasló jelentőségű müvelőjének számító hazai jogtudós életútját és tudományos pályáját ismerteti meg az olvasóval. A szerző, könyvének bevezető részében kiemeli, hogy a nyolc jogtudós pályájának bemutatásával és tudományos tevékenységének értékelésével célja a magyar magánjogtudomány elmúlt két évszázadáról való kép alkotása. Hangsúlyozza, hogy nem állt szándékában szisztematikus és átfogó tudománytörténetet írni. A kötetben közzétett tanulmányok a jogtudósok születési idejének sorrendjében követik egymást.

A tudósportrék sorát Frank Ignác (1788-1850): A rendi magyar magánjog tudományos összefoglalója című tanulmány nyitja. Frank Ignác magyar reformkorral összefüggő tudományos életmúve a történelmi magyar jogra (ius patrium) épül. A Principia iuris civilis Hungarici és A közigazság törvénye Magyarhonban, mely utóbbi a korábban latin nyelven publikált munka magyar nyelvű változata, ma is figyelmet érdemlö müvek. A közigazság törvénye Magyarhonban című munkája V. Ferdinánd rendeletéhez kapcsolódik. Az uralkodó az ország rendjeinek kívánságára ugyanis 1844-ben, a mü első részének, illetve első kötetének megjelenését megelőző évben elrendelte a tudományok magyar nyelven való tanítását. Az osztrák szerzők hatása a magyar nyelvü terminológiában is (például a „dologbani” és a „dologhozi” jogok közötti megkülönböztetés) kifejezésre jut. Frank Ignác az irodalom, a törvényhozás és a törvénykezés (bíráskodás) korában használatos szaknyelvét mellözve, korábban nem ismert kifejezéseket használt. A Magyar Tudományos Akadémia levelező tagjává történő választását követően Ősiség és elévülés címmel tartott székfoglaló előadásában az ősiség kérdését szélesebb összefüggésben, elsősorban a hitelhez kapcsolva elemezte. 1849 júliusának végén Bécsbe rendelték, abból a célból, hogy részt vegyen a Magyarországot érintő jogi kérdésekkel foglalkozó bizottság munkájában. Egyik munkájában az 
ösiség (aviticitas) történeti fejlődését, természetét és ennek felszámolásával összefüggő teendőkkel kapcsolatos nézeteit fejtette ki. Kiemelendő, hogy Frank Ignác, hasonlóan a 18. században élt és Egerben oktató professzorhoz, Huszty Istvánhoz, a Jurisprudentia practica seu commentarius novus in Ius Hungaricum címü, háromkötetes, több kiadást megért munka szerzőjéhez, a magyar magánjogot Werbőczytől függetlenül, maga alkotta rendszerben mutatta be. Az „europaizálódás” irányába ható változás a magyar civilisztikában, a német pandektisztika Friedrich Carl von Savigny nevéhez kapcsolódó irányzatának hatása, Frank Ignácnál mutatható ki legkorábban, aki jóllehet következetesen ellenezte a kodifikációt, mégis, Szalay László találó szavaival, ,egy új aera úttörőjének” tekinthető. Frank Ignác az 1823-ban közzétett, még az észjogi irányzat (Vernunftrecht), elsősorban Christian Wolff hatását tükröző Specimen elaborandarum institutionum iuris civilis Hungarici címủ mủvében a magyar földtulajdoni viszonyok tárgyalásánál római jogi fogalmakat használ. Mủveiben hivatkozott a korában ismert, már hatályban lévő magánjogi kódexekre, így a Porosz Általános Törvénykönyvre, a francia Code civilre és az Osztrák Polgári (Magánjogi) Törvénykönyvre éppúgy, mint a francia, osztrák és német magánjogi szakirodalomra. Frank Ignác munkáiban a feudális, hübéri magyar magánjogot dolgozta fel nemzetközi mércével mérve is magas színvonalon. Vékás Lajos hangsúlyozza, hogy Frank Ignác a magyar magánjogot belső fejlődés, nem pedig gyökeres átalakítás útján kívánta korszerüsíteni, a kor igényeivel összhangba hozni.

A kötet második, egyben legnagyobb terjedelmü, leghosszabb tanulmányának címe: Grosschmid Béni (1852-1938) és a Polgári Törvénykönyv. Grosschmid Béni, aki egyetemi hallgató korában nevét Zsögöd Benőre változtatta, majd 1904től ismét Grosschmid Béni néven tette közzé munkáit, Vékás Lajos szerint a magyar magánjogtudomány magas színvonalának folyamatosságát biztosítja Frank Ignác után, és Szladits Károlyra hivatkozva rámutat arra, hogy Grosschmid európai mércével mérve is eredeti gondolkodó, „szuverén szellem”, aki nem tartozik sem a történeti jogi iskolához sem pedig az érdekkutató irányzathoz. A Fejezetek kötelmi jogunk köréböl (a továbbiakban Fejezetek) címü, két kötetben publikált, két kiadást is megért monumentális munka Grosschmid Béni legjelentősebb és legeredetibb müve. Vékás Lajos a tanulmány egyik alfejezetében a Fejezetek jelentőségét és aktualitását a tulajdonátruházás jogi természetével kapcsolatos nézetek vonatkozásában vizsgálja. A teljesség igénye nélkül utalunk arra, hogy Grosschmid ebben a müvében a kötelem (obligatio) kétpólusú struktúráját elemezve kiemeli, hogy a relatív szerkezet nem tekinthető zártnak. Figyelemmel van a többalanyú kötelmi helyzetekre is. Vékás Lajos önálló alfejezetben mutat rá arra, hogy Grosschmid Béni érdeme a polgári törvénykönyv monista kódexként való koncipiálása, mely hatással volt a 2013. évi V. törvény, a 2014. március 15-én hatályba lépett új magyar Polgári Törvénykönyv monista kódexstruktúrájának elfogadására. A tanulmány ötödik alfejezete foglalkozik Grosschmid gondolatai- 
nak hatásával az új polgári törvénykönyv öröklési jogában. Vékás Lajos rámutat Grosschmid törvényes öröklésről írt tervezetének hatására a későbbi törvényhozásra, kiemelve $A$ köteles rész címü tanulmányának jelentőségét. A portré utolsó részében Grosschmid ,gondolatainak tükrében” az özvegyi jogot, az ági öröklést és a kötelesrészt vizsgálja.

A kötet harmadik tudósportréja (Szászy-Schwarz Gusztáv, 1858-1920) a magánjog és a római jog jeles müvelöjének, a budapesti Királyi Tudományegyetem professzorának és a Magyar Tudományos Akadémia levelező tagjának, SzászySchwarz Gusztávnak az életpályáját és tudományos munkásságát tekinti át. Vékás Lajos a portré első részében Szászy-Schwarz Gusztáv jogi személyről írt munkáit elemzi, kiemelve, hogy a jogtudós teóriájának kiindulópontja a római jog jeles művelője, Alois von Brinz nevéhez füződő célvagyon elmélet. A tanulmány szerzője utal arra, hogy Szászy-Schwarz saját teóriáját a monisztikus nézetek egyikének tartja. Kiinduló tétele szerint a jogalanyiság vonatkozásában nem lehet különbséget tenni a fizikai személy és a jogi személy között. Vékás Lajos részletesen foglalkozik Szászy-Schwarz Rudolf von Jheringről írt tanulmányával. Jhering több kiadást megért Geist des römischen Rechts auf den verschiedenen Stufen seiner Entwicklung és az alanyi jog fogalmát tisztázni hivatott, „epizódnak szánt”, Zweck im Recht címü müveit Szászy-Schwarz, aki Göttingenben Jhering tanítványa volt, és akit „Mesterének” tekintett, egészen eredeti, újszerű módon vizsgálja. Vékás Lajos egyetért Szászy-Schwarz megállapításával, aki szerint Jhering mindkét müve befejezetlen maradt. Kritikai éllel állapítja meg, hogy Szászy-Schwarz, bár elismeri a „Mester” 1861-ben publikált, a culpa in contrahendo doktrínáját megalapozó tanulmányának értékét, nem hangsúlyozza a tanulmány korszakos jelentőségét. Szászy-Schwarz Gusztáv felismeri Jhering Der Kampf ums Recht címü esszéjének kivételes gondolati gazdagságát, melyben a német jogtudós a „Geist” és a „Zweck” vezérgondolatait egyesíti. Vékás Lajos a portré utolsó részében Szászy-Schwarz Gusztáv kodifikációs munkásságát tekinti át. Az 1900-ban közzétett A magyar általános polgári törvénykönyv tervezete. Szászy-Schwarz az első szöveg öröklési jogi részének (1794-2043.§§) szerzője. Az első tervezet öröklési jogi részében található szabályok, vonatkozik ez különösen a törvényes öröklés szabályozására, tekintélyes része megtalálható az első magyar Polgári Törvénykönyvben éppúgy, mint a 2013. évi V. törvényben. Szászy-Schwarz Codificationalis dolgozatok címmel 1902-ben közzétett tanulmánykötete a 21. század polgári jogásza számára is hasznosítható gondolatokat tartalmaz mind a magánjogi kodifikációval, így például az ,általános rész” mellőzése tekintetében, mind pedig egyes jogintézmények, így például az ági öröklés vonatkozásában.

A kötet negyedik, Szladits Károly (1871-1956) és Magánjogi iskolája című portréja a magyar magánjogtudomány egyik legjelentősebb mủvelőjét mutatja be. Szladits magát Grosschmid Béni, akit egyik munkájában ,praeceptor Hun- 
gariae”-nek nevez és Szászy-Schwarz Gusztáv tanítványának vallja. A „Sub auspiciis Regis" doktorrá avatott Szladits Károly bíróságon kezdte jogászi pályáját. Magántanári képesítést fiatalon, 1908-ban szerzett a Budapesti Egyetem Jog- és Államtudományi Karán. 1917-ben lett ugyancsak Budapesten a magyar és az osztrák magánjog nyilvános rendes egyetemi tanára. A Magyar Tudományos Akadémia 1932-ben levelező, 1943-ban pedig rendes tagjává választotta. A jogtudomány képviselői közül elsőként tüntették ki Kossuth-díjjal 1953-ban. Vékás Lajos a portré első részében Szladits fiatalkori politikai orientációját és annak lehetséges állomásait tekinti át. A portré Szladits Károly tankönyveivel és tudományos munkásságával foglalkozó részében a szerző Szladits $A$ magyar magánjog vázlata (Vázlat), több kiadásban és átdolgozott formában megjelent munkájának elemzése kapcsán kiemeli, hogy a Vázlat általános tanai struktúrájának hatása a mai polgári jogi tankönyvirodalomban is kimutatható. A továbbiakban a Szladits által szerkesztett, hatkötetes, 1938 és 1942 között megjelent Magyar magánjog jelentőségére mutat rá. A „magnum opus” általa írt általános részében Szladits megfogalmazza a polgári magánjog jellemző vonásait, melyek a 21. század második évtizedében is érvényesek. A portré utolsó részében Vékás Lajos a Szladits-iskolával foglalkozva megállapítja, hogy a Szladits-iskola tagjainak egy szűkebb kör, éspedig a Szladits vezette magánjogi szeminárium résztvevői tekinthetők, melynek legjobbjai monografikus igényü munkák szerzői. Szladits Károly életpályája szemléletes példája a tudományos kutatásban és a professzori szintű utánpótlás nevelésében egyaránt megmutatkozó kivételes tehetség harmóniájának.

A könyv ötödik tanulmánya (Nizsalovszky Endre, 1894-1976) Nizsalovszky Endre munkásságát értékeli. Nizsalovszky 1929-ben szerzett magántanári képesítést Debrecenben. Tanári pályáját is a Debreceni Egyetemen kezdte meg a kereskedelmi és a váltójog professzoraként. 1938-ban került a budapesti Pázmány Péter Tudományegyetemre, ahol a polgári törvénykezési jog tanszék professzora volt. Szladits Károly nyugalomba vonulását követően vette át a magyar magánjogi tanszéket 1943-ban. Az általa vezetett katedrákat meghívás alapján nyerte, ami a kivételes szakmai elismerés jele. Aktív szerepet vállalt különösen a Magyar Tudományos Akadémián és a Magyar Jogász Egyletben. 1949-től politikai támadások érték. 1956-ban az MTA Állam- és Jogtudományi Bizottsága elnökévé választották. 1956-ban került sor a Magyar Tudományos Akadémia főtitkárárává választására. 1957 szeptemberében egyetemi tanári tisztéből azonnali hatálylyal elbocsátották, és megfosztották akadémiai tisztségeitől is. Első publikációja 1921-ben jelent meg. Bár a szociális tárgyú írásokkal nem hagyott fel, az 1920-as években föképpen társasági jogi és valorizációs témákkal foglalkozott. 1928-ban jelentek meg első nagyobb lélegzetű dologi jogi és zálogjogi munkái, így az Értékjog és zálogjog és a Magyar magánjog mai érvényben. II. Dologi jog. Az 1930-as években jogbölcseleti, kereskedelmi jogi és perjogi munkákat publikált $A$ látszat 
a jogban, Az érdekkutató jogtudomány a magánjogban, A kereskedelmi törvény és joggyakorlata, Grosschmid és a kereskedelmi jog, Az alanyi magánjog és a perjog és Perképesség-jogképesség címmel. Az évtized végén jogszabálytannal, társadalompolitikával és jogtörténettel foglalkozott: Apponyi társadalompolitikája. Serlegbeszéd, Magánjogi kodifikáció. Illés József jubileuma alkalmából és A római jog szelleme. A második világháború után több tankönyvet írt: Kötelmi jog II., Kötelmi jog I., Magyar családi jog, Magyar polgári jog I. általános rész. Az 1950-es években részt vett a Polgári Törvénykönyv kodifikációjában. Családi joggal, szerzői joggal és jogtörténettel, később pedig orvos-egészségügyi joggal foglalkozott. Az ekkor született monográfiái később angol, francia és német nyelven is megjelentek. Kutatásai eredményeire a nemzetközi szakmai közvélemény is felfigyelt. 1984-ben egykori tanítványai a Tanulmányok a jogról címủ posztumusz kötettel tisztelegtek emléke előtt. Több írása ekkor kerülhetett először az olvasók elé. Egy évtizeddel később az Eötvös Loránd Tudományegyetem és a Magyar Tudományos Akadémia rehabilitálta. 1994-ben jelent meg a tisztelői által jegyzett Nizsalovszky Endre Emlékkönyv címü kötet. Nizsalovszky Endre a katedrán kiválóan ötvözte az elméleti és a gyakorlati megközelítést, egyben nagy gondot fordított az egyes magánjogi jogintézmények elméleti-történeti alapjainak bemutatására is. A tanulmány szerzője a jogtudós néhány jelentős művének rövid bemutatására is vállalkozik. Mủveinek belső értéke, gazdag tudományos munkássága alapján válik a magánjogot magas szinten művelő jogtudósok méltó társává.

Vékás Lajos könyvének hatodik portréja (Világhy Miklós, 1916-1980) Világhy Miklós professzornak, a Magyar Tudományos Akadémia levelező tagjának életútját ismerteti meg az olvasóval. Világhy Miklós a Pázmány Péter Tudományegyetem Jog- és Államtudományi Karán szerzett diplomát 1939-ben. Szladits Károly tanítványa volt. Első tudományos dolgozata, mely a tulajdonjog-fenntartás kérdését elemezte, még hallgató korában, 1937-ben jelent meg. Ezt követte a perlési megbízásról írt munkája, melyet a Szladits Károly 70. születésnapja alkalmából kiadott ünnepi kötetben, 1941-ben publikált. A tíz éven át joggyakorlat területén müködő Világhy Miklós 1949-ben kezdte meg oktatói munkáját. A Pázmány Péter Tudományegyetem Jog- és Államtudományi Karán (1950 szeptemberétől az Eötvös Loránd Tudományegyetem [ELTE] Állam- és Jogtudományi Karán) először a Munkajogi Tanszéket, később a II. számú Polgári Jogi Tanszéket vezette. Három éven át volt a kar dékánja, majd mandátuma lejártát követően, az 1956/1957. évi tanévben betöltötte az ELTE rektori tisztét is. Három éven át, 1962 és 1965 között az egyetem tudományos rektorhelyettese volt. Világhy Miklós tudományos munkásságában a magyar polgári jog anyagának átfogó feldolgozása, a szellemi alkotások jogi védelme - különös tekintettel az iparjogvédelemre -, a gazdasági jog kérdése és a jogi személyiség problémája tekinthetők centrális jelentőségünek. Kiemelendőek továbbá a nemzetközi magánjoggal kapcsolatos 
kutatásai. Kiemelendő, hogy mint tekintélyes professzor különös figyelemmel kísérte a római jogi kutatások hazai és nemzetközi eredményeit.

A könyv hetedik tanulmánya (Eörsi Gyula, 1922-1992) Eörsi Gyula egyetemi tanár, a Magyar Tudományos Akadémia rendes tagjának életútját és tudományos munkásságát elemzi. Vékás Lajos tanulmánya bevezető részében hangsúlyozza, hogy az 1978-ban Állami-díjjal, 1983-ban pedig Akadémiai Aranyéremmel kitüntetett Eörsi Gyula tudományos müködése „két korszakhatár közé esik”. Tanulmányait a budapesti Pázmány Péter (1950. szeptember 15. óta Eötvös Loránd Tudományegyetem) Jog- és Államtudományi Karán folytatta. Tanulmányai befejezését követően 1948-1949-ben állami ösztöndíjjal a Sorbonne-on volt vendéghallgató. 1947-1948-ban bírósági aljegyző a központi kerületi járásbíróságon, majd 1951-ig törvényszéki bíróként főelőadó az Igazságügyi Minisztériumban, előbb a magánjogi, ezt követően pedig a törvényelökészítő osztályon. 1951-ben konzulként múködik az Amerikai Egyesült Államokban, New York Cityben és Washingtonban. 1952-ben visszatér Magyarországra. 1952 és 1957 között az Igazságügyi Minisztérium Törvény-előkészítő Főosztályának vezetője. Félállásban az ELTE Polgári Jogi Tanszékén lett egyetemi docens azt követően, hogy korábban már oktatott a Közgazdaságtudományi Egyetemen és a Szegedi Tudományegyetemen. 1956-ban kapja meg egyetemi tanári kinevezését. 1978-ban az ELTE rektorává választották, ezt a tisztségét 1984. június 30-ig viselte. Egyetemi állása mellett az MTA Állam- és Jogtudományi Intézet polgári jogi osztályának vezetője, később igazgató-helyettese. 1986-ban kutatóprofesszori megbízást kap. 1967-ben, illetve 1970-ben a Dar-es Salam-i Egyetem, 1973-ban pedig a Stockholmi Egyetem vendégprofesszora. 1952-ben védte meg az állam- és jogtudományok kandidátusi, 1956-ban akadémiai doktori értekezését. 1962-ben lett az MTA levelező, 1973-ban pedig rendes tagja. Akadémiai tisztségei mellett a Magyar Iparjogvédelmi Egyesület alelnöke, valamint a német Gesellschaft für Rechtsvergleichung tagja és tiszteletbeli doktora volt. Vékás Lajos kiemeli, hogy Eörsi Gyulának meghatározó szerepe volt a szovjet mintát követő, ideológiai alapokon nyugvó jog, jogtudomány és jogi oktatás meghonosításában. Fő kutatási területe a polgári jog volt. Emellett foglalkozott összehasonlító polgári joggal (magánjoggal), a jog és a gazdaság közötti kapcsolattal és iparjogvédelemmel. Az 1950-es években a szocialista polgári jog elméleti alapjait rakta le, könyvet írt a tervszerződésekről és a kártérítési jogról. Behatóan foglalkozott a polgári jogi felelősség elméleti és gyakorlati kérdéseivel is. A portré szerzője utal Eörsi Gyula Világhy Miklóssal társszerzőként írt, több kiadásban megjelent polgári jogi tankönyvének jelentőségére.

A kötet utolsó, nyolcadik portréja (Magánjogi kérdések jogelméleti megközelítése Peschka Vilmos [1929-2006] müveiben) a 2001-ben Széchenyi-díjjal kitüntetett Peschka Vilmos, a Magyar Tudományos Akadémia rendes tagja tudományos munkásságát mutatja be, melynek tengelyében a jogelmélet és a magánjogtudo- 
mány áll. Peschka Vilmos az Eötvös Loránd Tudományegyetemen folytatott jogi tanulmányokat. 1957 szeptemberétől 1999-ben történt nyugalomba vonulásáig a Magyar Tudományos Akadémia Állam- és Jogtudományi Intézetében dolgozott fóállásban, pályája utolsó szakaszában kutatóprofesszorként. 1960-ban lett az ELTE Polgári Jogi Tanszékének oktatója. Egyetemi tanári kinevezést 1972ben kapott. A jogviszonyelmélet alapvetö kérdései címmel 1960-ban jelent meg nyomtatásban 1958-ban megvédett kandidátusi értekezése. Jogforrás és jogalkotás címü értekezésével 1968-ban szerezte meg az állam- és jogtudományok doktora címet. Peschka Vilmos már korai munkáiban kritizálta a szocialista normativizmust. Nézete szerint a Legfelsőbb Bíróság jogszabály-értelmezés során meghozott irányelveivel és elvi döntéseivel ténylegesen jogot alkot. A jog értéke vonatkozásában a döntő elem az, hogy mennyiben járul hozzá az emberi lényeg megvalósulásához. A modern jogfilozófia alapproblémái címü, 1972-ben megjelent könyvében a nyugat-európai jogfilozófia problémafelvetései ismertetésével és elemzésével járult hozzá a magyar jogtudomány gazdagításához. Jelentősek érett alkotói korszakában írt munkái, így az 1979-ben megjelent A jogszabályok elmélete, az 1988-ban kiadott $A$ jog sajátossága és az Appendix „, A jog sajátosságához" címủ müvei. Vékás Lajos portréjában Peschka Vilmosnak a magánjogi kodifikációval, a magánjogtudomány jogbölcseleti alapjaival és a jogügyletek értelmezésével foglalkozó munkáit elemzi részletesebben. Anton Friedrich Justus Thibaut és Friedrich Carl von Savigny kodifikációs vitájával foglalkozva hangsúlyozza, hogy Peschka Vilmos a „Kodifikationsstreit” alapkérdésében Savigny jogbölcseleti és teoretikus alapokon nyugvó nézetét fogadja el. Vékás Lajos a továbbiakban utal a kodifikációs vita aktualitására az 1959-ben elfogadott első magyar Polgári Törvénykönyv és a 2013. évi V. törvény (második magyar Polgári Törvénykönyv) elökészítésénél. Peschka Vilmos több fiatalkori tanulmányban is elemezte a magyar magánjogtudomány jogbölcseleti alapjait, különös figyelemmel a történeti jogi iskola hatására Frank Ignác, Wenzel Gusztáv, Suhayda János, Zlinszky Imre, Herczeg Mihály és Grosschmid Béni műveire. Bár a „kötelező ideológiai elfogultság" nyomta rá bélyegét ezekre a munkáira, gondolatgazdagságuk miatt ma is tájékozódási alapot jelentenek a hazai magánjogtudomány filozófiai alapjai, forrásai vonatkozásában. A portré utolsó részében Vékás Lajos Peschka Vilmosnak a jogügyletek értelmezésével foglalkozó gondolatait tekinti át, rámutatva azoknak a bírói gyakorlatban való figyelembevételének lehetőségére és szükségességére. Peschka Vilmos joggal tekinthető a 20. század utolsó évtizedeiben alkotó legjelentősebb hazai jogfilozófusnak, akinek munkássága a magánjogtudomány területén ma is figyelmet érdemel.

A kitűnő stílusban megírt, magas színvonalú, kismonográfiának is tekinthető tanulmányok egy hiánypótló, kitűnő arányokkal megszerkesztett kötetben olvashatók. A magyar magánjogtudomány jeles alakjait bemutató, négy esetben - Nizsalovszky Endre, Világhy Miklós, Eörsi Gyula és Peschka Vilmos - személyes 
visszaemlékezésre is támaszkodó tudósportrékat magában foglaló kötet joggal tarthat számot a jogtudományi kutatásokat folytatók, a jogásztársadalom valamennyi tagja és a jogtudó értelmiségünk iránt érdeklődő szélesebb olvasóközönség érdeklődésére.

(Vékás Lajos: Fejezetek a magyar magánjogtudomány történetéböl. Budapest: HVG-ORAC Kiadó, 2019, 185 o.)

Hamza Gábor

az MTA rendes tagja, egyetemi tanár Eötvös Loránd Tudományegyetem Állam- és Jogtudományi Kar 